\title{
ЗАСТОСУВАННЯ ІНФОРМАЦЙНО-КОМУНІКАЦЙНИХ ТЕХНОЛОГІЙ У НАВЧАЛЬНОМУ ПРОЦЕСІ БУКОВИНСЬКОГО ДЕРЖАВНОГО МЕДИЧНОГО УНІВЕРСИТЕТУ
}

\author{
Т. М. Бойчук, I. В. Геруш, В. М. Ходоровський \\ Буковинський державний медичний університет
}

\section{USE OF INFORMATION AND COMMUNICATION TECHNOLOGIES IN EDUCATIONAL PROCESS IN BUKOVYNA STATE MEDICAL UNIVERSITY}

\author{
T. M. Boychuk, I. V. Herush, V. M. Khodorovskyi \\ Bukovyna State Medical University
}

\begin{abstract}
У статті висвітлено застосування різних форм інформаційно-комунікаційних технологій у навчальному процесі Буковинського державного медичного університету. Використання таких технологій поряд із традиційними формами організації навчального процесу дозволяє поліпшити його якість, робить його більш комфортним та цікавим для студента, більш контрольованим - для викладача.
\end{abstract}

The article highlights the use of various forms of information and communication technologies in educational process in Bukovyna State Medical University. Using these technologies along with traditional forms of school organization can improve its quality, making it more comfortable and interesting for students, more controlled - for teachers.

Вступ. Соціально-економічні перетворення, що відбуваються в Україні, світові тенденції гуманізації, інтеграції та глобалізації суспільства визначили нові пріоритети розвитку освітньої галузі [2]. Серед пріоритетних напрямів державної політики щодо розвитку вищої освіти в контексті євроінтеграції України визначено проблему постійного підвищення якості освіти, модернізацію її змісту та форм організації навчальновиховного процесу. Бурхливе зростання потоку наукової інформації, обсяг якої збільшується з кожним роком, спонукає шукати нові, більш ефективні технології, способи і засоби навчання, які дозволили б дати більше інформації за ту ж одиницю навчального часу і піднести їїбільш яскраво і доступно, щоб вона легше сприймалася і краще запам'ятовувалася. Застосування інформаційно-комунікаційних технологій (ІКТ) відноситься до числа тих факторів, які сприяють підвищенню інтенсивності та якості процесу навчання $[1,3]$.

У даній статті розглядається досвід використання ІКТ у навчальному процесі Буковинського державного медичного університету.

Основна частина. У навчальний процес Буковинського державного медичного університету упродовж останніх років впроваджені такі IКТ:

- сервер дистанційного навчання;

( Т. М. Бойчук, I. В. Геруш, В. М. Ходоровський
- центр підготовки абітурієнта;

- вебінари.

Сервер дистаниійного навчання. У Буковинському державному медичному університеті у 2010 році створений сервер дистанційного навчання (moodle.bsmu.edu.ua) на базі системи управління навчанням "MOODLE". MOODLE (Modular ObjectOriented Dynamic Learning Environment) - це віртуальне навчальне середовище, яке являс собою мережеву програмну оболонку для створення електронних навчально-методичних комплексів. За допомогою цієї системи студент може дистанційно, через Інтернет, ознайомитися з навчальним матеріалом, який подається у вигляді різнотипних інформаційних ресурсів (текст, відео, анімація, презентація, електронний посібник), виконати завдання та відправити результати їх виконання на перевірку викладача.

На сервері дистанційного навчання для кожної навчальної дисципліни створені електронні навчальні курси, які містять організаційно-методичні та навчально-довідкові блоки, а також засоби самоконтролю та перевірки знань студентів (рис. 1).

Організаційно-методичний блок електронного навчального курсу забезпечує умову щодо методичної організації самостійної роботи студента як при вивченні дисципліни в цілому (інформація щодо структу- 


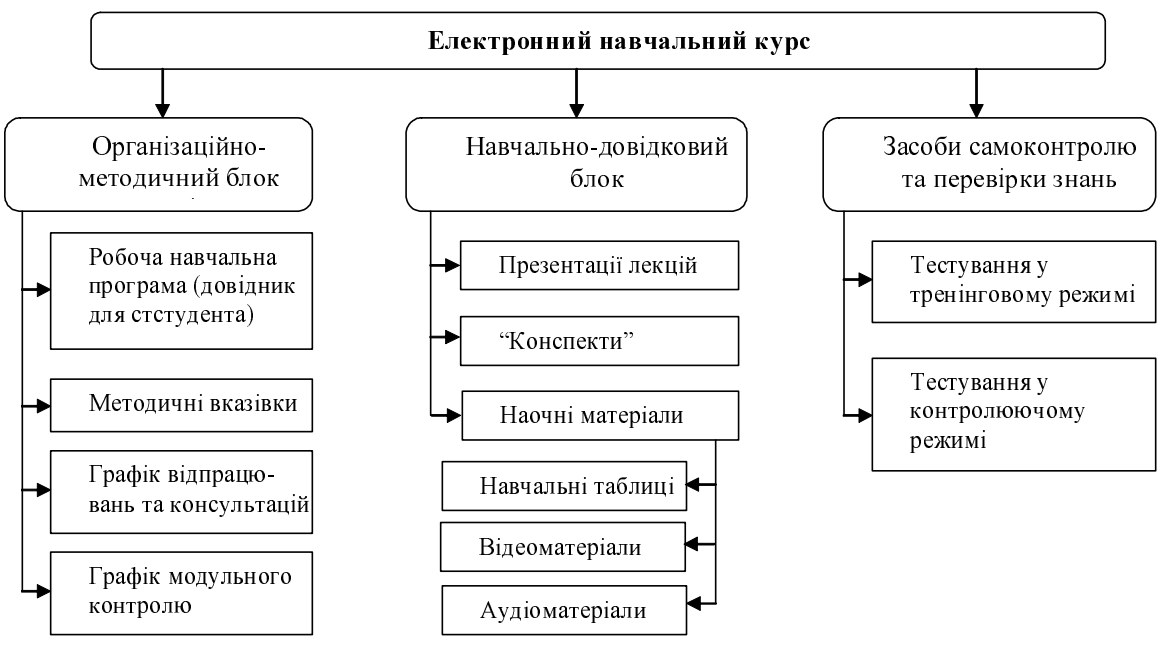

Puc. 1. Структурна схема електронного навчального курсу на сервері дистанційного навчання БДМУ.

ри, цілі та змісту дисципліни, принципів оцінювання, календарних та тематичних планів занять, графіків консультацій, проміжнихтапідсумкових контролів), так і при підготовці до конкретного навчального заняття (інформація щодо актуальності теми заняття, його тривалості, навчальної мети, питання для самоконтролю, список рекомендованої навчальної літератури).

Навчально-довідковий блок складається із структурованих електронних навчальних матеріалів, зміст яких надає студенту теоретичні відомості з теми заняття у повному обсязі (презентації лекцій, "конспекти"). Мультимедійні можливості системи "MOODLE" дозволяють максимально унаочнити навчальний матеріал у вигляді навчальних таблиць, відео- та аудіороликів тощо. Це дає змогу посилити інтерес студентів до навчального матеріалу, покращити його засвоєння, а на практичному (семінарському) занятті оптимальніше використати відведений час. Крім того, мультимедійні ресурси дозволяють студентам вже на етапі підготовки до навчального заняття ознайомитися $33 \mathrm{D}$-анатомічними моделями, у відеорежимі побачити методики проведення клінічного чи лабораторно-інструментального обстеження пацієнта, хід виконання експериментів, оперативних втручань, прослухати аудіолекції.

Важливим етапом підготовки студента до практичного заняття $\epsilon$ самоконтроль. Для цього в електронних навчальних курсах в кінці кожного тематичного розділу дисципліни створений елемент "Тестові завдання для самоконтролю”, який дає можливість студенту пройти онлайн-тестування як з обмеженням по часу (контролюючий режим), так і без нього (тренінговий режим). У тренінговому режимі студент має змогу перевірити відповідь на поточне завдання, а також отримати підказку. Тренінговий режим само- контролю дозволяє студенту самостійно виявляти проблеми в структурі своїх знань та вживати заходів щодо їх ліквідації. Викладач має змогу перевірити результати тестування студентів, побачити кількість спроб та затрачений час, визначити найбільш “легкі” та "проблемні" для студентів тестові завдання. Останнє дозволяє викладачу напередодні проведення навчального заняття адаптувати план його проведення, а саме правильно визначити акценти як у розрізі групи, так і в розрізі конкретного студента, що дозволяє індивідуалізувати навчальний процес.

Сервер дистанційного навчання БДМУ дозволяє сформувати та надати студенту не тільки організаційно-методичний та навчально-довідковий контент, а й забезпечує контроль самостійної діяльності студента. Зокрема викладач може одержати інформацію щодо кількості відвідувань серверу; часу перебування в електронному навчальному курсі; переліку опрацьованих ресурсів та елементів курсу; кількості та якості виконаних завдань. Викладачу доступні результати діяльності конкретного студента, а також аналіз роботи академічної групи в цілому. Така інформація дає змогу викладачу напередодні проведення навчального заняття правильно скласти план його проведення, а саме правильно визначити акценти як у розрізі групи, так і в розрізі конкретного студента, що дозволяє індивідуалізувати навчальний процес.

На даний час робочими навчальними програмами не передбачено обов'язкове використання студентами серверу дистанційного навчання БДМУ під час самостійної роботи, проте сервер користується неабиякою популярністю серед студентства. Результати опитування, яке було проведеноу 2013 році, засвідчило, що близько 90 \% студентів щодня використовують сервер при підготовці до навчальних занять. На сервері, за даними 
сервісу інтернет-статистики “Hotlog”, у середньому на добу реєструється 4600-4900 переглядів.

Популярність СДН сприяла позиціям БДМУ у рейтингу "Webometrics Ranking of World's Universities", який визначає місця університетів світу за показником їх наявності в мережі “Інтернет”. У січні 2014 року БДМУ увійшов до 3000 кращих університетів світу, посівши 12-ту сходинку серед ВНЗ України та 1-шу серед вищих медичних навчальних закладів.

Центр підготовки абітурієнта. ІКТ також використовуються при підготовці слухачів до вступу у вищі навчальні заклади України. На платформі “MOODLE” створений Центр підготовки абітурієнта (zno.bsmu.edu.ua) (рис. 2).

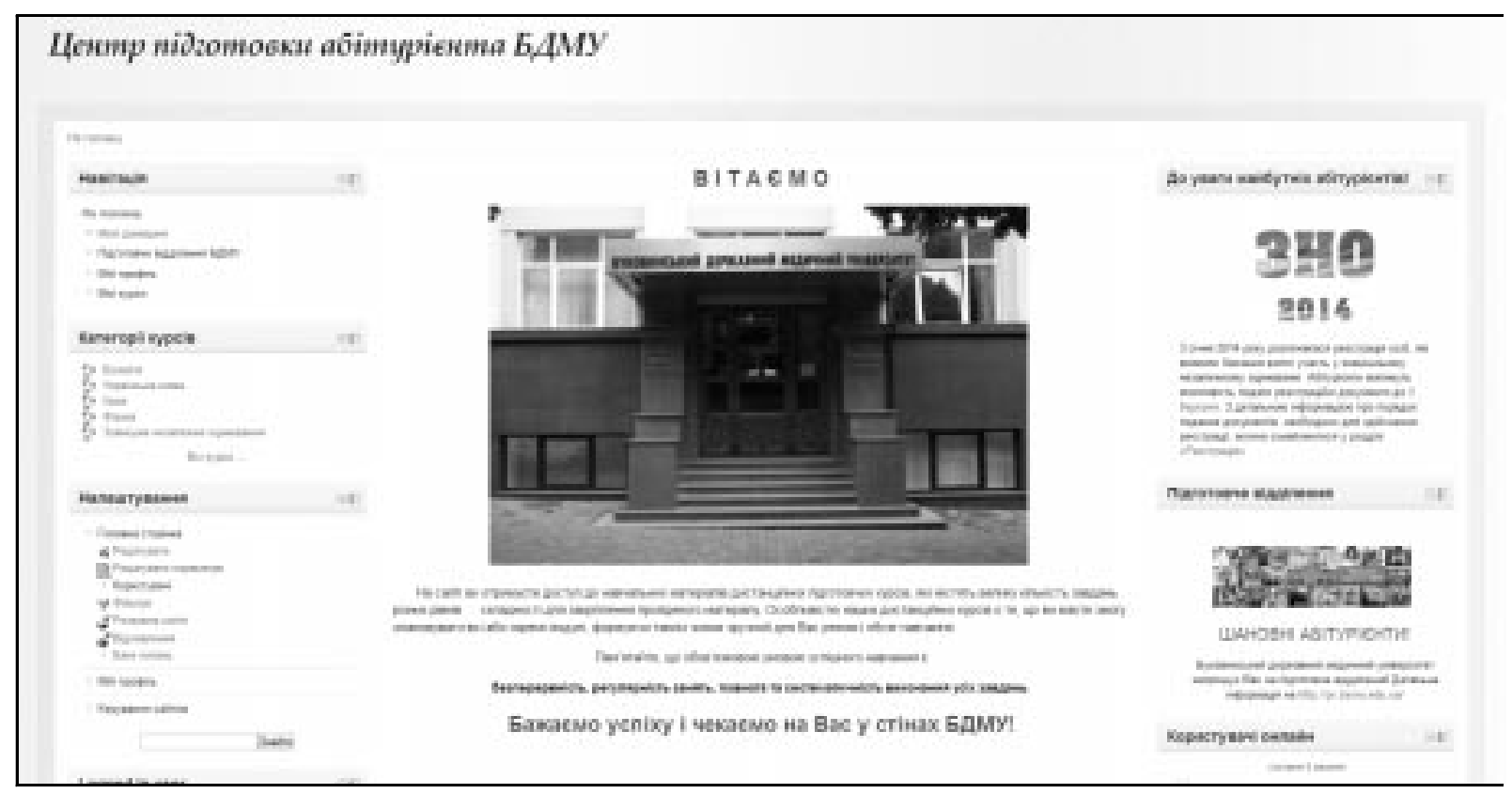

Puc. 2. Центр підготовки абітурієнта БДМУ (zno.bsmu.edu.ua).

На даному веб-ресурсі випускники 11 класів мають змогу абсолютно безкоштовно в дистанційному режимі підготуватися до складання зовнішнього незалежного оцінювання якості освіти з біології, хімії, фізики, української мови та літератури.

Електронні навчальні курси складені відповідно до програм ЗНО і містять повні та актуальні бази тестових завдань різного формату. Підготовкою випускників ЗОШ керують досвідчені викладачі профільних кафедр університету. Така форма навчання абітурієнтів є унікальною серед медичних ВНЗ і користується великою популярністю. Щорічно дистанційною підготовкою до ЗНО займаються 400-600 випускників 11 класів, серед них мешканці не тільки Західного регіону, а й Вінницької, Київської, Одеської, Черкаської, Запорізької, Донецької та Луганської областей. Про ефективність цього віртуального навчального середовища свідчать такі показники: 100 \% користувачів zno.bsmu.edu.uа успішно склали $3 \mathrm{HO} \mathrm{у}$ 2013 році, з них понад 80 \% стали студентами 1-го курсу БДМУ.

Вебінари. Ще однією з форм використання IКТ у навчальному процесі БДМУ є проведення вебінарів.
Вебінар (від англ. web+seminar, webinar) - це технологія, яка забезпечує проведення інтерактивних навчальних заходів у синхронному режимі і надає інструменти для дистанційної колаборативної (спільної) роботи учасників.

Зазвичай для вебінару готується презентація, на основі якої будується спілкування. Кожен учасник вебінару виконує свою роль, яку визначає інтерфейс віртуального класу і права на використання певних функцій, які можуть передаватися іншим учасникам. У вебінарі передбачено три ролі: модератор (той, хто організує та керує вебінаром), ведучий (як правило, вчитель) та слухач (учень).

Наразі вебінари повністю впроваджені в навчальний процес підготовчого відділення університету. Викладачами підготовчого відділення систематично проводяться вебінари з біології та хімії, де після спільного обговорення теми вебінару всіма учасниками он-лайн конференції (ведучим і слухачами) розв'язуються тематичні тестові завдання, які передбачені програмою ЗНО (рис. 3).

$32011 / 2012$ навчального року розпочато апробацію використання технології вебінарів на післядипломно- 


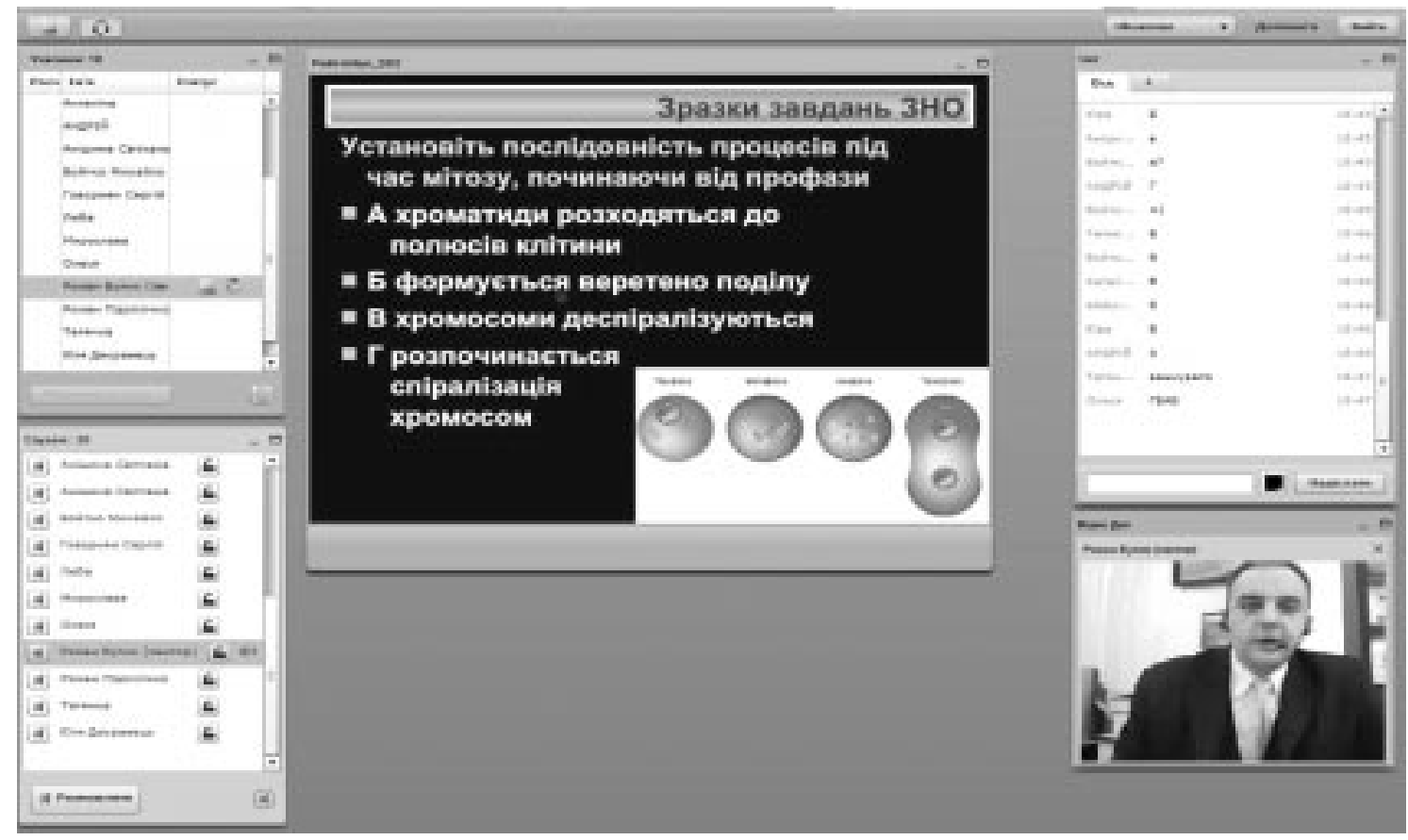

Puc. 3. Вебінар з біології проводить викладач підготовчого відділення БДМУ.

му етапі підготовки лікарів, а саме під час циклів тематичного удосконалення. Робочими навчальними програмами таких 2-тижневих циклів передбачено проведення лекційних занять у вигляді вебінарів упродовж 1-го тижня навчання, а практичних та семінарських - упродовж 2-го тижня. Такий підхід дозволяє зекономити час та витрати лікарів-слухачів на проїзд від місця проживання до відповідної кафедри. Така форма проведення циклів тематичного удосконалення була з цікавістю та підтримкою сприйнята лікарями-слухачами факультету післядипломної освіти БДМУ.

Результати впровадження інформаційно-комунікаційних технологій у навчальний процес були презентовані на V Міжнародній виставці “'Сучасні заклади

\section{Література}

1. Дубасенюк О. А. Інноваційні навчальні технологіїоснова модернізації університетської освіти / О. А. Дубасенюк // Освітні інноваційні технології у процесі викладання навчальних дисциплін : зб. наук.-метод. праць / за ред. О. А. Дубасенюк. - Житомир : Вид-во ЖДУ, 2004.-C. 3-14.

2. Кузняк Н. Б. Використання інформаційно-комунікаційних технологій у вищих медичних навчальних закладах / Н. Б. Кузняк, В. А. Гончаренко, Р. Р. Дмитренко // Клінічна та експериментальна патологія. -2013. - Т.12, №2.-С. 197-199. освіти -2014" (Київ, 18-20 березня 2014 р.), на якій Буковинський державний медичний університет був нагороджений Золотою медаллю та дипломом у номінації "Сучасні програми, інноваційні підходи та рішення для підвищення якості освіти".

Висновки. У Буковинському державному медичному університеті впроваджені та успішно використовуються сучасні інформаційно-комунікаційні технології, які у поєднанні з традиційними формами організації навчання дозволяють удосконалити та оптимізувати процес підготовки студентів, слухачів підготовчого відділення та лікарів-інтернів до навчальних занять, зробити його більш комфортним, доступним, контрольованим та ефективним.

3. Литвин А. Перспективи телекомунікаційних технологій у вищій технічній освіті / А. Литвин, О. Литвин, Ю. Гето // Інформація, комунікація, суспільство 2013 : матеріали 2-ї Міжнародної наукової конференції ІКС-2013, 16-19 травня 2013 року, Україна, Львів, Славське / Міністерство освіти і науки України, Національний університет "Львівська політехніка". - Львів : Видавництво Львівської політехніки, 2013. - C. $120-121$. 